\title{
Bioactivity and health effects of Mentha spicata
}

\author{
Leong Ay Kee ${ }^{1}$, Amal Bakr Shori ${ }^{2 *}$ and Ahmad Salihin Baba ${ }^{1}$ \\ ${ }^{1}$ Biomolecular Research Group, Division of Biochemistry, Institute of Biological Sciences, Faculty of Science, University of Malaya, 50603 Kuala Lumpur, Malaysia \\ ${ }^{2}$ Department of Biological Sciences, Faculty of Science, King Abdulaziz University, Jeddah 21589, Saudi Arabia
}

\begin{abstract}
Traditional medicine provides an important health care service and can be used as alternate therapy. Plants are rich in phytochemical compounds that offer a source of dietary ingredients used to treat various ailments and problems. Spearmint (Mentha spicata L) belongs to the family Lamiaceae and is a rich source of polyphenols. These polyphenols have shown numerous of biological activities and health benefits. Therefore, the present study shows the bioactivity and health effects of spearmint.
\end{abstract}

\section{Introduction}

Spearmint (Mentha spicata $L$ ), belongs to the family Lamiaceae. The plants of this family are a rich source of polyphenols and thus possessing strong antioxidant properties [1,2]. Spearmint is indigenous to northern England [3] and is cultivated in areas with climate ranging from tropical to temperate, such as America, Europe, China, South Africa and Brazil [4,5]. Nowadays, spearmint is widely grown throughout all regions in the world [6].

Spearmint is also known as brown mint, garden mint, lady's mint, and sage of Bethehem [3]. Spearmint is a creeping rhizomatous [7] and perennial herbs [8]. The leaves are broad and sharply serrate. The trademark of mint family is the stem which is in square-shaped [9]. Spearmint produces rightly and long pink or white flowers in slender spikes. Spearmint leaves possess a characteristic aromatic odour and pungent taste. However, in contrast to peppermint and Japanese mint, the cooling after-effect is absent in spearmint $[8,9]$.

\section{Constituents}

The constituents found in spearmint are shown in Table 1. Carvone, a phenolic compound, is the main constituent found in spearmint oil, followed by limonene $[7,10]$. Carvone is reported to be potential in inhibiting bacterial growth [11], as well as to act as fungicide [12] and insect repellent [13]. Carvone also reversibly suppresses the sprouting in stored potatoes or flower bulbs [14].

Table 1. Result of MS essential oil analysis by gas chromatography-mass spectrometry

\begin{tabular}{|c|c|c|c|}
\hline Compound & Percentage (\%) & Compound & Percentage (\%) \\
\hline$\beta$ - myrcene & 0.25 & Trans-carveol & 0.30 \\
\hline Limonene & 11.50 & Carvone & 78.76 \\
\hline F-terpinene & 0.16 & $\begin{array}{c}\text { Dihydrocarvyl } \\
\text { acetate }\end{array}$ & 0.57 \\
\hline Menthone & 1.01 & L-carveol & 0.32 \\
\hline Menthol & 1.00 & $\beta$ - bourbonene & 1.23 \\
\hline Terpinen-4-ol & 0.99 & Trans-caryophyllene & 1.04 \\
\hline Q-terpinol & 0.31 & $\gamma$-amorphene & 0.21 \\
\hline Dihydrocarveol & 0.22 & a-amorphene & 0.16 \\
\hline Cis-dihydrocarveol & 1.43 & Other compounds & 0.11 \\
\hline Dihydrocarvone & 0.43 & Total & $\mathbf{1 0 0 . 0 0}$ \\
\hline
\end{tabular}

(Adapted from Shahbazi, [35])
Carvone renders the characteristic smell of spearmint. The smell is smooth and near analogous to fennel oil [15]. However, (S)-carvone and (R)- carvone contribute to the odor of spearmint and caraway seeds respectively. Both are enantiomers of a biological material but elicit different response. In addition, S-carvone possess high antioxidant activity [9].

\section{Bioactivity}

It is reported that spearmint possesses antioxidant activity [16] on account of the presence of phenolic acids, flavonoids, carvone and ascorbic acid in leaves [17]. According to Scherer, et al. [18], spearmint can become an alternate form for synthetic antioxidants which bring harmful effects.

The biological activities of spearmint also include antiinflammatory, antimicrobial and sedative [19]. The good antimicrobial activity is attributed to the high concentration of carvone [18]. In addition, spearmint is carminative, antispasmodic and diuretic [20].

\section{Uses}

Both fresh and dried spearmint plants are widely used in a variety of application [21]. Since ancient times, both western and eastern cultures have been practiced spearmint as medical and aromatic plants [22]. In term of biological uses, spearmint acts as insecticides [23], antispasmodics and anti-platelets [24]. Moreover, spearmint is used as antimicrobial [25] and antioxidant agents [26].

In term of medical uses, spearmint is considered as an herbal medicine in folkoric remedies for treating of colds and flu, respiratory tract problems, gastralgia, hemorrhoids, and stomachache [20,27,28]. Spearmint is extracted in the form of oil and is regularly used in medicine [15]. Bensabah, et al. [29] states that spearmint leaves are

Correspondence to: Amal Bakr Shori, Department of Biological Sciences, Faculty of Science, King Abdulaziz University, Jeddah 21589, Saudi Arabia, E-mail: shori_7506@hotmail.com

Key words: spearmint, constituents, bioactivity, health/ benefit

Received: December 02, 2017; Accepted: December 11, 2017; Published: December 13, 2017 
generally taken as a tea in which its carminative properties can help to treat digestive disorders, fever and minor ailments [3]. Furthermore, spearmint has broadly applied to treat various illnesses. For instances, nausea, vomiting and gastrointestinal disorders $[30,31]$.

In term of food uses, spearmint is used in food, confectionery, and chewing gum industries $[15,21,29,32]$. Spearmint contributes to food preservation [18] and imparts food taste and aroma [32]. Spearmint is used in Iran as flavouring agent in food products such as cheese and doogh [33]. Besides, spearmint is added in Indian and Italian cuisine, either in fresh or dried form, to fish and shellfish plates before or after cooking [20,34]. Owing to the antioxidant, antiradical and chelating properties it possesses, the incorporation of spearmint in food can help to maintain the equilibrium of redox status in organism as well as to improve safety and effect on human wellbeing [10]. Spearmint has been used broadly in cosmetic and soap [21,29,32], as well as toothpaste, breath freshener and antiseptic mouth rinse [30,31].

\section{Conclusion}

Phenolic compounds in spearmint were exhibited many biological activities. Thus, spearmint has great potential to be used in medical and functional foods applications. Further studies and advanced researches are needed to enhance its properties and increase its applications.

\section{References}

1. Gulluce M, Sahin F, Sokmen M, Ozer H, Daferera D, et al. (2007) Antimicrobial and antioxidant properties of the essential oils and methanol extract from Mentha longifolia L. ssp. longifolia. Food Chem 103: 1449-1456.

2. Bimakr M, Rahman RA, Taip FS, Ganjloo A, Salleh LM, et al. (2011) Comparison of different extraction methods for the extraction of major bioactive flavonoid compounds from spearmint (Mentha spicata L.) leaves. Food Bioprod Process 89: 67-72.

3. Peter KV (Ed.) (2006) Handbook of herbs and spices (Vol. 3). Woodhead publishing.

4. Lawrence BM (2007) The composition of commercially important mints.Mint: Genus Mentha. Taylor \& Francis Group, Boca Raton, FL, pp: 88-89.

5. Hajlaoui H, Trabelsi N, Noumi E, Snoussi M, Fallah H, et al. (2009) Biological activities of the essential oils and methanol extract of tow cultivated mint species (Mentha longifolia and Mentha pulegium) used in the Tunisian folkloric medicine. World J Microbiol Biotechnol 25: 2227-2238.

6. Ghderi PGhderi P, Ahmadi R, Balkanyian F, Moridikyia A, Mahdavi E, et al. (1975) The essential oils.5th printing, D. Van. Nostard Company, Inc. (Princeton, New Jersey), I: 50-83; III: 676-683.

7. Jirovetz L, Buchbauer G, Shahabi M, Ngassoum MB (2002) Comparative investigations of the essential oil and volatiles of spearmint. Perfum Flavor 27: 16-22.

8. Husain A, Janardhanan KK (1965) Stolon rot of Japanese mint. Curr Sci 34: 156-157.

9. Elmastaş M, Dermirtas I, Isildak O, Aboul-Enein HY (2006) Antioxidant Activity of S-Carvone Isolated from Spearmint (Mentha Spicata L. Fam Lamiaceae). J Liquid Chromate Related Technol 29: 1465-1475.

10. Snoussi M, Noumi E, Trabelsi N, Flamini G, Papetti A, et al. (2015) Mentha spicata essential oil: chemical composition, antioxidant and antibacterial activities against planktonic and biofilm cultures of Vibrio spp. strains. Molecules 20: 14402-14424. [Crossref]

11. Helander IM, Alakomi HL, Latva-Kala K, Mattila-Sandholm T, Pol I, et al. (1998) Characterization of the action of selected essential oil components on Gram-negative bacteria. J Agri Food Chem 46: 3590-3595.

12. Smid EJ, de Witte Y, Gorris LG (1995) Secondary plant metabolites as control agents of postharvest Penicillium rot on tulip bulbs. Postharvest Biol Technol 6: 303-312.

13. Lee S, Tsao R, Peterson C, Coats JR (1997) Insecticidal activity of monoterpenoids to western corn rootworm (Coleoptera: Chrysomelidae), twospotted spider mite (Acari: Tetranychidae), and house fly (Diptera: Muscidae). J Econo Entomol 90: 883-892. [Crossref]

14. Kerstholt RPV, Ree CM, Moll HC (1997) Environmental life cycle analysis of potato sprout inhibitors. Indus Crops Prod 6: 187-194.
15. Abu-zeid EN (1992) Aromatic Plants and their Agricultural and Pharmaceutical Products. 1st edition. Al Dar Al Arabia for Printing and Distribution. Cairo, Egypt, pp: 473.

16. Dorman HJ, Koşar M, Kahlos K, Holm Y, Hiltunen R (2003) Antioxidant properties and composition of aqueous extracts from Mentha species, hybrids, varieties, and cultivars. J Agr Food Chem 51: 4563-4569. [Crossref]

17. Guimarães R, Barreira J, Barros L, Carvalho AM, Ferreira IC (2011) Effects of oral dosage form and storage period on the antioxidant properties of four species used in traditional herbal medicine. Phytother Res 25: 484-492.

18. Scherer R, Lemos MF, Lemos MF, Martinelli GC, Martins JDL, et al. (2013) Antioxidan and antibacterial activities and composition of Brazilian spearmint (Mentha spicata L.) Indus. Crops Prod 50: 408-413.

19. Kiselova Y, Ivanova D, Chervenkov T, Gerova D, Galunska B, et al. (2006) Correlation between the in vitro antioxidant activity and polyphenol content of aqueous extracts from Bulgarian herbs. Phytother Res 20: 961-965. [Crossref]

20. Tetik F, Civelek S, Cakilcioglu U (2013) Traditional uses of some medicinal plants in Malatya (Turkey). J Ethnopharmacol 146: 331-346. [Crossref]

21. Lawrence BM (Ed.) (2006) Mint: the genus Mentha. CRC Press.

22. Park KJ, Vohnikova Z, Brod FPR (2002) Evaluation of drying parameters and desorption isotherms of garden mint leaves (Mentha crispa L.). J Food Eng 51: 193199

23. Samarth RM, Kumar A (2003) Mentha piperita (Linn.) leaf extract provides protection against radiation induced chromosomal damage in bone marrow of mice. Indian J Exp Boil 41: 229-237. [Crossref]

24. Tognolini M, Barocelli E, Ballabeni V, Bruni R, Bianchi A, et al. (2006) Comparative screening of plant essential oils: phenylpropanoid moiety as basic core for antiplatelet activity. Life Sci 78: 1419-1432. [Crossref]

25. Sulieman AME, Abdelrahman SE, Rahim AMA (2011) Phytochemical analysis of loca Spearmint (Mentha spicata) leaves and detection of the antimicrobial activity of its oil. J Microbiol Res 1: 1-4.

26. Mata AT, Proença C, Ferreira AR, Serralheiro MLM, Nogueira JMF, et al. (2007) Antioxidant and antiacetylcholinesterase activities of five plants used as Portuguese food spices. Food Chem 103: 778-786.

27. Asekun OT, Grierson DS, Afolayan AJ (2007) Effects of drying methods on the quality and quantity of the essential oil of Mentha longifolia L. subsp. Capensis. Food Chem 101: 995-998.

28. Kanatt SR, Chander R, Sharma A (2007) Antioxidant potential of mint (Mentha spicata L.) in radiation-processed lamb meat. Food Chem 100: 451-458.

29. Bensabah F, Houbairi S, Essahli, M, Lamiri, A, Naja, J. 2013. Chemical Composition and Inhibitory Effect of the Essential Oil from Mentha Spicata Irrigated by Wastewater on the Corrosion of Aluminum in 1 Molar Hydrochloric Acid. Port Electrochimica Acta 31: 195-206.

30. Kumar P, Mishra S, Malik A, Satya S (2011) Insecticidal properties of Mentha species: a review. Indus. Crops Prod 34: 802-817.

31. Tyagi AK, Malik A (2011) Antimicrobial potential and chemical composition of Mentha piperita oil in liquid and vapour phase against food spoiling microorganisms. Food Control 22: 1707-1714.

32. Igoumenidis PE, Lekka EG, Karathanos VT (2016) Fortification of white milled rice with phytochemicals during cooking in aqueous extract of Mentha spicata leaves. An adsorption study. LWT-Food Sci Technol 65: 589-596.

33. Singh R, Shushni MA, Belkheir A (2015) Antibacterial and antioxidant activities of Mentha piperita L. Arab J Chem 8: 322-328.

34. Kizil S, Hasimi N, Tolan V, Kilinc E, Yuksel U (2010) Mineral content, essential oil components and biological activity of two mentha species (M. piperita L, M. spicata L.). Turk J Field Crops 15: 148-153.

35. Shahbazi Y (2015) Chemical Composition and In Vitro Antibacterial Activity of Mentha spicata Essential Oil against Common Food-Borne Pathogenic Bacteria. $J$ Pathog 2015: 5 .

Copyright: (C2017 Kee LA. This is an open-access article distributed under the terms of the Creative Commons Attribution License, which permits unrestricted use, distribution, and reproduction in any medium, provided the original author and source are credited. 